\title{
DISTAL SIGNATURES OF, AND VECTORS TO, HYDROTHERMAL ORES IN CARBONATES IN THE CANDELARIA-PUNTA DEL COBRE DISTRICT, CHILE
}

STEPHEN PIURKOWSKY ${ }^{1}$, ZHAOSHAN CHANG $^{1}$ AND PAULA BRUNETTO ${ }^{2}$

${ }^{1}$ Colorado School of Mines

${ }^{2}$ Lundin Mining Chile SpA

Presenting Author: spiurkowsky@mymail.mines.edu

The Candelaria-Punta del Cobre district is a $\mathrm{NE}$ trending $\mathrm{Cu}-$ $\mathrm{Au}-(\mathrm{Zn}-\mathrm{Ag})$ mineralized zone within the Chilean Iron belt. IOCG mineralization in the district is commonly hosted in volcanic rocks of the Punta del Cobre formation and in calcareous rocks of the Chañarcillo Group. Deposits are mainly found in structurally controlled breccias (Santos, Alcaparossa) but may be of manto type (e.g. Candelaria). Lower grade mineralization also occurs in skarns hosted in calcareous sediments of the Chañarcillo group located stratigraphically above the volcanic rocks. The Chañarcillo group is well exposed in the eastern and southern peripheries of the district. Developed in these sediments are fluid escape structures (calcite veins) that are the distal expressions of spent mineralizing fluid(s) from the hydrothermal system. In this study, 86 samples of fluid escape veins and the wall rock they are hosted in were collected along traverses that extend from known orebodies to distal locations in barren rock. Samples of vein and wall rock were submitted for bulk rock geochemical analysis. Preliminary results of LA-ICP-MS analysis of calcite in vein and wall rock material from traverse \#1 show a trend in $\mathrm{Mn}$ concentration over $8 \mathrm{~km}$ distance. Manganese in veins is weakly elevated close to the orebody $(\sim 1,000-2,500$ $\mathrm{ppm})$. It increases to $\sim 15,000 \mathrm{ppm}$ about $2.5 \mathrm{~km}$ away from the main ore zone, then decreases steadily away to $100 \mathrm{~s}$ of ppm at locations about $8 \mathrm{~km}$ away. Calcite in veins has a different trace element geochemical signature than calcite in wall rock. On average, veins have lower $\mathrm{Mn}$ and $\mathrm{Fe}$ concentration than the wallrock calcite. Wallrock calcite, particularly calcite in fossils, has higher $\mathrm{P}$ (up to $\sim 100 \mathrm{ppm}$ ) and $\mathrm{S}$ (up to $\sim 1,000 \mathrm{ppm}$ ) than calcite in veins (dominantly below detection limits of $10 \mathrm{~s}$ to a few $100 \mathrm{ppm}$ ). The concentrations of $\mathrm{Sr}, \mathrm{Cr}, \mathrm{Ba}, \mathrm{U}$ and $\mathrm{Th}$ are also relatively lower in vein calcite. Calcite in veins shows various florescence colors (e.g., white, light blue, pink) under short-wave ultraviolet light, likely related to the $\mathrm{Mn} / \mathrm{Fe}$ ratio. 